\title{
GRB2-Associated-Binding Protein 1
}

National Cancer Institute

\section{Source}

National Cancer Institute. GRB2-Associated-Binding Protein 1. NCI Thesaurus. Code C107456.

GRB2-associated-binding protein 1 (694 aa, $77 \mathrm{kDa}$ ) is encoded by the human GAB1 gene. This protein is involved in intracellular signaling from growth factor receptors. 